\title{
Influence of sewage pollution on a rocky intertidal community dominated by the mytilid Brachidontes rodriguezi
}

\author{
J. J. López Gappa, A. Tablado, N.H. Magaldi \\ Museo Argentino de Ciencias Naturales 'Bernardino Rivadavia', Av. Angel Gallardo 470, 1405 Buenos Aires, Argentina
}

\begin{abstract}
The characteristic Brachidontes rodriguezi community was absent from the highly polluted intertidal area surrounding a sewage outfall at Quequén (Argentina). It began to recover in lower tidal levels with better water renewal and shorter dessication periods. The chlorophyte Ulva lactuca was the most abundant organism at intermediate pollution levels, but reached its highest abundance in association with B. rodriguezi. The puimonate limpet Siphonaria lessoni, the chlorophytes Cladophora sp. and Enteromorpha compressa, and blue-green algae increased in the vicinity of the outfall. A decrease in epilithic community biomass in the highly polluted area could be inferred from changes in percent cover, stratification and bare substratum proportion. Highest diversity was reached at intermediate pollution levels. Diversity decreased at higher levels due to low specific richness and also in relatively unpolluted areas due to space monopolization by $B$. rodriguezi. Therefore, sewage pollution could be regarded as a disturbance factor preventing space monopolization by the most successful competitor Sewage effects on the benthic community were similar to the decrease in abundance observed towards upper intertidal levels. Community structure proved to be a better pollution indicator than seawater variables, since it can be considered as reflecting an average of varying environmental conditions.
\end{abstract}

\section{INTRODUCTION}

The effects of domestic wastes on marine communities have been studied mainly in the northern hemisphere. In developed countries, sewage usually receives primary or secondary treatment in order to decrease its nutrient and organic matter content, and is discharged to the sea through pipeline systems opening at some distance from shore (Gerlach 1981). The influence of sewage pollution on intertidal communities has been assessed in relatively few cases (Borowitzka 1972, Munda 1974, 1980a, b, Littler \& Murray 1977). A study similar to the present one was carried out in California by Littler \& Murray (1975), who made a detailed analysis of the impact of very low sewage volumes on an intertidal community dominated by macrophytes.

The use of benthic communities in marine pollution assessment is based on the concept that they reflect not only conditions at the time of sampling but also conditions to which the community was previously exposed (Reish 1987). Therefore, benthic organisms can be good indicators of the pollution degree in a given area (Anger 1977, Leppäkoski 1979, Young \& Young 1982, Reish 1986).

The present study was carried out at Quequén (Buenos Aires Province, Argentina). At this locality, untreated sewage is discharged directly into a rocky intertidal community dominated by the bivalve Brachidontes rodriguezi. No previous reports exist on intertidal community structure at Quequén. However, several studies deal with fouling communities at Necochea Power Station in Quequén Harbor (Bastida \& Brankevich 1980 , 1981, 1982, Brankevich et al. 1984, 1988) and information about intertidal communities and populations is available for Mar del Plata, located ca $120 \mathrm{~km}$ NE of Quequén (Olivier et al. 1966, Olivier \& Penchaszadeh 1968, Bastida et al. 1971, Penchaszadeh 1973a).

The main aim of this study was to evaluate community changes caused by different pollution levels, and the tolerance of benthic organisms to pollution stress. We suggest that the pollution gradient observed along the shoreline could also be interpreted as a disturbance gradient affecting the benthic community. 


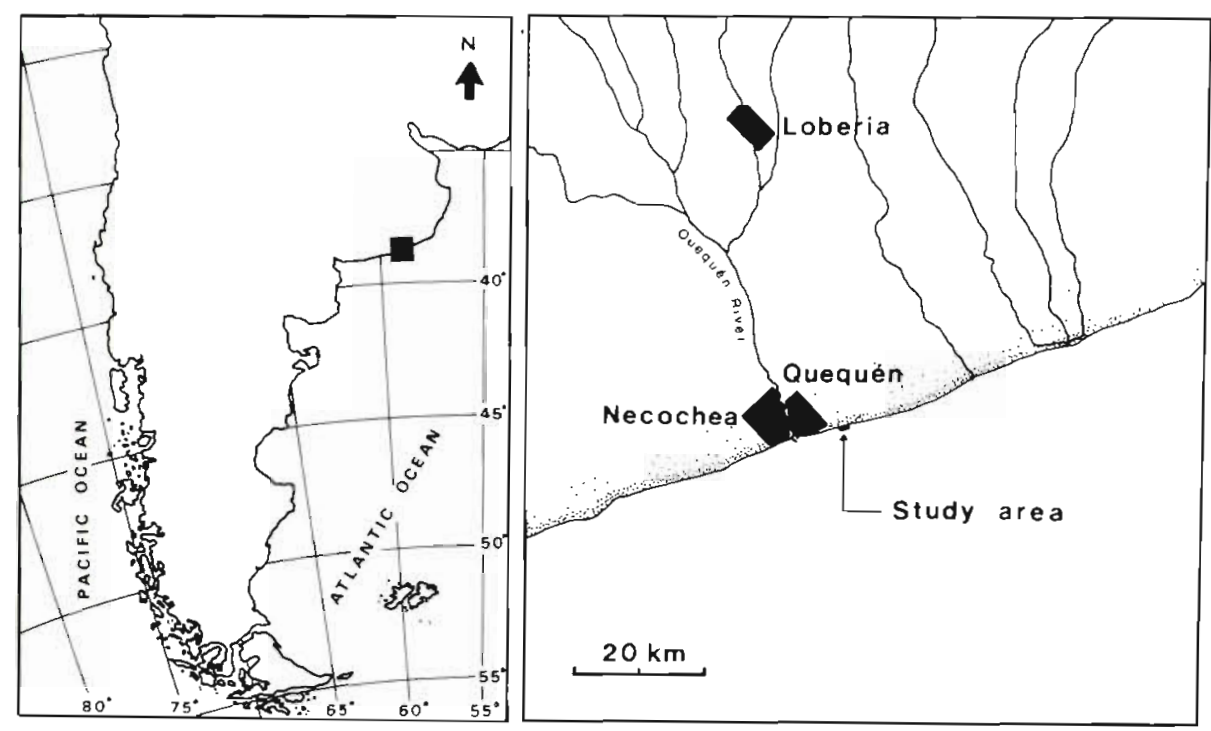

Fig. 1. Location of study area

\section{STUDY AREA}

According to the 1980 National Census, the current population of Necochea and Quequén (Buenos Aires Province) is about' 65000 inhabitants. Information obtained at the Department of Public Works and Services of Necochea Municipality indicates that ca $65 \%$ of houses and buildings are connected to the sewage network, which represents ca 42000 inhabitants. Domestic effluents do not receive any kind of treatment. There is only one pumping station within the urban area, which propels part of the effluent towards the end of the pipeline system. Four $\mathrm{km}$ eastwards of Quequén Harbor, between Quequen and the summer resort of Costa Bonita (38 $34^{\prime} \mathrm{S}, 58^{\circ} 38^{\prime} 30^{\prime \prime}$ W) (Fig. 1), raw sewage is discharged onto the shore through a pipeline measuring $60 \mathrm{~cm}$ in diameter at its opening.

No information on discharged volume or chemical and biological characteristics of the effluent was available. Based on flux measured at the pipeline opening, we obtained a rough estimate of ca 14 million 1 of untreated sewage per day. The outfall terminus is located in the lower intertidal area. However, there is a leak through a hole of irregular shape (ca $40 \times 25 \mathrm{~cm}$ ), on the upper side and $13.5 \mathrm{~m}$ before the pipeline end, in the mid-intertidal area.

The intertidal area consists of a rocky substrate composed of loess plattorms, separated from a coastal cliff 7 to $8 \mathrm{~m}$ high by sand strips. At low tide, 2 irregular parallel breaks of 40 to $60 \mathrm{~cm}$ height can be seen along the coast. The first divides the intertidal into 2 levels, and the second roughly indicates the beginning of the subtidal zone (Fig. 2). Grooves lying perpendicular to the shoreline are common in the lower intertidal area, as well as holes produced by the boring bivalve
Lithophaga patagonica. There are 2 unequal daily tides, reaching a maximum average amplitude of $1.28 \mathrm{~m}$. The horizontal intertidal distance ranges from 40 to $70 \mathrm{~m}$ in the study area.

Changes in the benthic community caused by sewage outfall can be clearly seen from the top of the cliff. The affected area becomes wider to the east, owing to the influence of the west-east coastal current. The total affected area extends over ca $400 \mathrm{~m}$ of shoreline, comprising an area in which the Brachidontes rodriguezi community is absent $(0$ to $75 \mathrm{~m}$ west and 0 to $150 \mathrm{~m}$ east of the outfall), and also areas which show a gradual recovery of this community $(75$ to $150 \mathrm{~m}$ west and 150 to $250 \mathrm{~m}$ east of the outfall).

\section{METHODS}

A preliminary survey of the study area and collection of samples for taxonomic identification of species were carried out during October 1987 and March 1988. During spring (23 to 29 October 1988), the benthic community was sampled along 6 transect lines perpendicular to the shore, at $50 \mathrm{~m}$ intervals from 0 to $250 \mathrm{~m}$ to the west of the outfall. Nine to 14 quadrats were placed along each transect, at $5 \mathrm{~m}$ intervals (Fig. 2). A total of 65 quadrats were taken, all in the intertidal except for one quadrat at the beginning of the subtidal, $250 \mathrm{~m}$. from the outfall.

Percent cover was chosen as the method for quantifying relative abundance of each species, due to difficulties in estimating algal density, and since substratum is regarded as the main limiting factor in intertidal benthic ecology (Dayton 1971). A $45 \times 45 \mathrm{~cm}$ square grid made up of nylon lines intersecting every $5 \mathrm{~cm}$ and 
Fig. 2. Schematic map of study area showing outfall and transect locations. Symbols represent quadrat groups obtained from multivariate analyses. 1 , quadrats with high proportion of bare substratum; 2, crusts of blue-green algae, 3 , Brachidontes rodriguezi community; 4 . tide-pools dominated by Ulva lactuca; 5 , subtidal quadrat dominated by Corallina officinalis. Transect profiles with relative quadrat heights are shown on the right

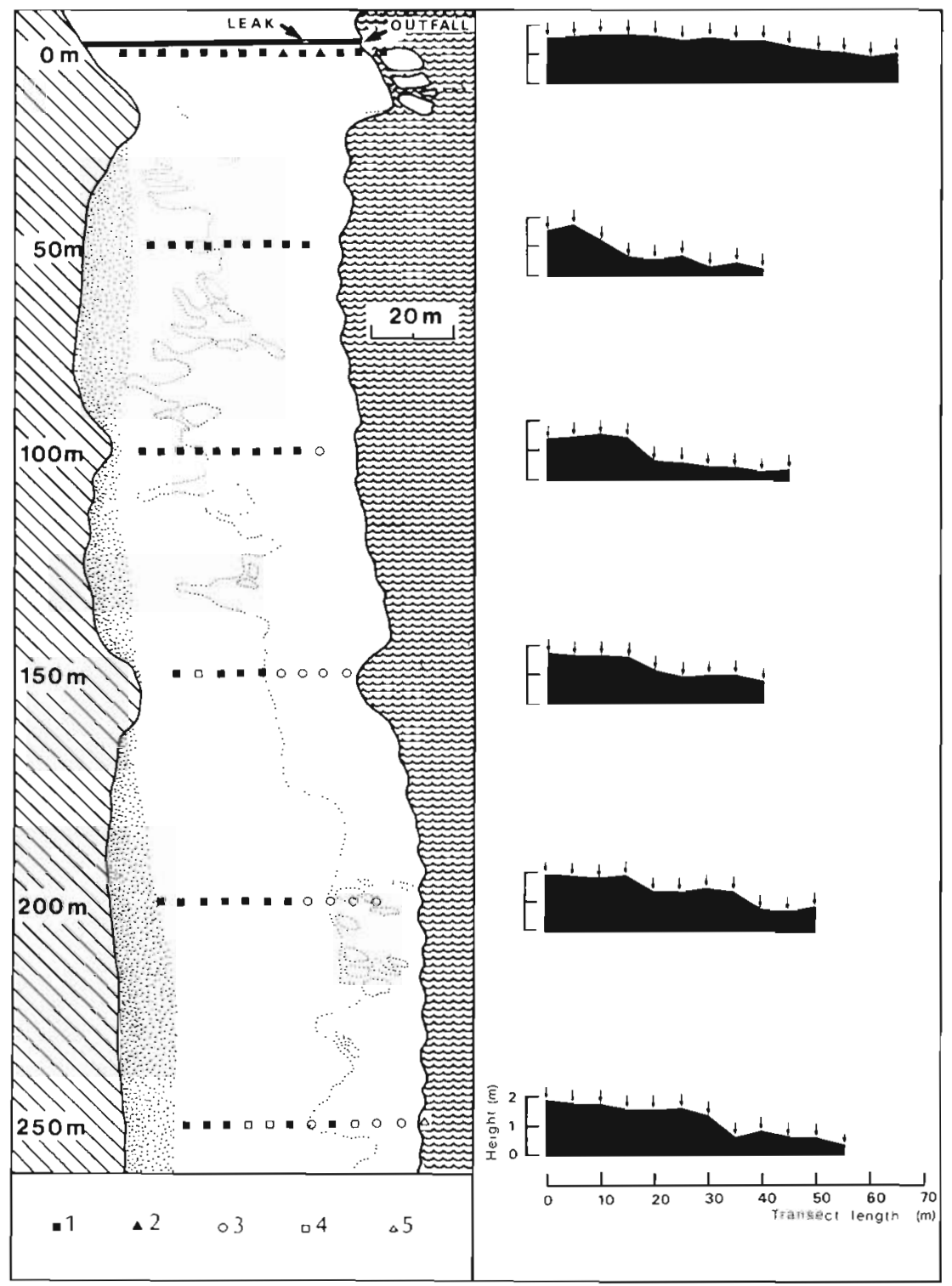

totalling 100 intersection points was used for percent cover estimates of macrobenthic organisms. Presence of species or bare substratum was recorded under each intersection. Percent cover was then calculated for each quadrat and transect. Species which were observed within quadrats but did not fall under a grid intersection were assigned a cover value of $0.5 \%$. Due to overlapping of organisms many quadrats had total cover values higher than $100 \%$. The difference between total cover value and $100 \%$ was used as an estimate of community stratification.

The data were also used to calculate species richness, diversity ( $\mathrm{H}^{\prime}$ index; Shannon \& Weaver 1949) and evenness ( $J^{\prime}$ index; Pielou 1969) in each of the 65 quadrats and 6 transects. Diversity values of transects were compared using Kruskal-Wallis' and Mann-Whitney's non-parametric tests (Siegel 1956).

Associations among quadrats were analyzed by cluster analysis using the UPGMA clustering algorithm (Romesburg 1984). The distance index Mean Character Difference (Cain \& Harrison 1958) was chosen because it produced a good group discrimination and the highest cophenetic correlation coefficient (Sokal \& Rohlf 1962). An ordination of the 65 quadrats was also performed by Principal Components Analyses (PCA) (Neff \& Marcus 1980). Calculations were done on an Epson QX-10 computer programmed by one of the authors (A. T.).

Blue-green algae were treated as a single taxonomic unit. 
Due to total lack of information about seawater in the study area, several physical and chemical analyses were performed in an attempt to quantify pollution levels. Temperature was measured in situ and water samples were collected at $50 \mathrm{~m}$ intervals to the west of the outfall in order to assess salinity, $\mathrm{pH}$, dissolved oxygen (DO), biochemical oxygen demand $\left(\mathrm{BOD}_{5}\right)$ and total and coliform bacteria in the laboratory. DO and $\mathrm{BOD}_{5}$ were analyzed using the azide modification of Winkler's iodometric method (American Public Health Association 1971). Density of total bacteria was estimated by counting colonies growing on agar seeded with 0.1 and $0.01 \mathrm{ml}$ of sample and the most probable number of coliform bacteria was assessed by standard methods.

Since the 6 transects and water samples were taken at regular intervals along the pollution gradient, we considered that the scores on the first PCA axis could be used as a measure of pollution stress and performed 2 independent PCAs on the basis of seawater and benthos data, respectively.

Relative vertical heights of the 65 quadrats were measured with a sighting level. A point on the pipeline was taken as reference level and was assigned an arbitrary value of $2 \mathrm{~m}$. Average height was calculated for each transect. Quadrats were grouped according to their relative heights in $0.2 \mathrm{~m}$ intervals.

\section{RESULTS}

The benthic community was composed of 13 macrophyte species and 11 macroinvertebrates. Their percent cover in each quadrat and transect are given in Table 1

Whereas bare sustratum represented 65 to $75 \%$ between 0 and $100 \mathrm{~m}$ from the outfall, these values decreased to between 45 and $62 \%$ in the 3 transects between 150 and $250 \mathrm{~m}$ (Table 1, Fig. 3). The proportion of bare substratum was always high in the upper intertidal and decreased in the lower intertidal only in transects located far from the outfall (Fig. 4). This was largely due to Brachidontes rodriguezi, since its abundance is negatively correlated with proportion of bare sustratum ( $\mathrm{r}=-0.73, \mathrm{p}<0.01)$. It was the dominant species between 150 and $250 \mathrm{~m}$ (Fig. 3), particularly at lower levels (Fig. 4), where it reached densities of 30000 to 33000 ind. $\mathrm{m}^{-2}$. However, it was almost completely absent from transects between 0 and $50 \mathrm{~m}$ from the outfall.

Other species that showed a decrease in abundance with increasing pollution levels were the rhodophyte Porphyra leucosticta (sensu Coll \& Oliveira Filho) and the chlorophyte Ulva lactuca (Figs. 3 and 4 ). The latter was the most abundant species in 50 and $100 \mathrm{~m}$ transects and together with Brachidontes rodriguezi showed the highest percent cover values at 150 and $250 \mathrm{~m}$ (Table 1, Fig. 3). Abundances of $U$. lactuca and $B$. rodriguezi were found to be positively correlated $(\mathrm{r}=$ $0.46, p<0.05$ ) and co-occurrence of both species largely accounts for increases in community stratification. The latter was minimal at the most polluted transect $(0 \mathrm{~m})$, and was low at 50 to $100 \mathrm{~m}$, where U. lactuca was common but $B$. rodriguezi was rare. Maximum stratification values were reached at 150 and $250 \mathrm{~m}$ due to the occurrence of mid-intertidal tide-pools dominated by U. lactuca (Table 1, Fig. 3).

Sea anemones were more frequent in 150,200 and $250 \mathrm{~m}$ transects than in the vicinity of the outfall. Pseudoparactis tenuicollis lives on the valves of Brachidontes rodriguezi, as reported by Zamponi (1979a). Phymactis clematis, Sagartianthus fasciarum and Bunodactis cf. marplatensis were often found in tide-pools and holes within the $B$. rodriguezi commun-

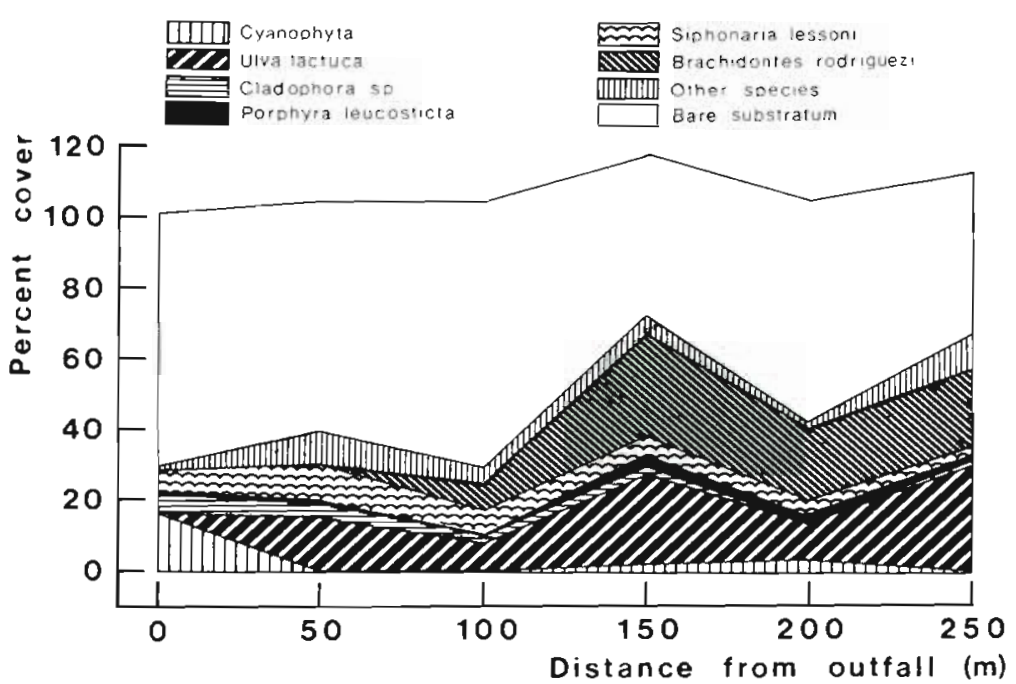

Fig. 3. Proportion of bare substratum and percent cover of main macrobenthic species along the pollution gradient (total transect values may exceed $100 \%$ due to community stratification) 
ity. A similar distribution was observed for the isopod Sphaeroma serratum and the decapod Cyrtograpsus angulatus, which were found mainly in upper and midintertidal tide-pools between 50 and $250 \mathrm{~m}$ from the outfall.

A different distribution pattern was shown by cyanophytes. They occurred in small upper intertidal tide-pools in transects located away from the outfall, but were particularly abundant in areas surrounding the pipeline breakage (Figs. 2 and 4), where they formed extensive crusts reaching a cover of $74 \%$. The chlorophytes Enteromorpha compressa and Cladophora sp. also increased their percent cover in the vicinity of the outfall (Table 1, Fig. 4), where they were frequent in small tidepools and crevices. In the highly polluted area, the filamentous thalli of Cladophora sp. were covered by dense tufts of the sessile ciliate Zoothamnium sp. and colonial diatoms such as Navicula cf. grevillei.

The pulmonate limpet Siphonaria lessoni increased its percent cover in transects near the outfall, particularly at the $50 \mathrm{~m}$ transect (Table 1, Fig. 3). On the other hand, in relatively unpolluted areas where Brachidontes rodriguezi dominated on the substratum, S. lessoni was able to settle in upper levels, but only small specimens could be found on the mytilid in mid-and lower intertidal areas (Fig. 4).

The barnacles Balanus amphitrite and B. glandula were completely absent in areas dominated by Brachidontes rodriguezi. They occurred only in the most polluted transects (0 to $50 \mathrm{~m}$; Table 1 ).

The bivalve Mytilus platensis reached its highest frequency ( $80 \%$ of quadrats) in the $100 \mathrm{~m}$ transect, and its highest abundance in the upper intertidal area of the $150 \mathrm{~m}$ transect, although it was scarce or absent from transects located either very close to or very far from the outfall (Table 1). The cespitose rhodophyte Gelidiella cf. nigrescens showed a similar distribution pattern. It reached its highest percent cover on the 50 and $100 \mathrm{~m}$ transects, but was rare or absent in the heavily polluted area and also in unpolluted areas dominated by Brachidontes rodriguezi. This alga was particularly abundant on semipolluted transects during the October 1987 survey, but was also found intermingled with $B$. rodriguezi in cleaner areas

The filamentous chlorophyte Chaetomorpha sp. and the phaeophyte Scytosiphon lomentaria were occasionally observed in upper and mid-intertidal tide-pools and crevices. On the other hand, the chlorophyte Bryopsis plumosa and the rhodophytes Ceramium sp., Polysiphonia cf. urceolata and Corallina officinalis were frequent in lower intertidal tide-pools. In the subtidal, Brachidontes rodriguezi disappeared and $C$. officinalis became the dominant organism, forming a conspicuous fringe and reaching a percent cover of $59 \%$ (Table 1).
The infauna of sandy substrata at the lower intertidal and subtidal in the 50 and $100 \mathrm{~m}$ transects was dominated by the spionid polychaete Boccardia sp., which reached densities of around $500000 \mathrm{ind} . \mathrm{m}^{-2}$.

Changes in diversity, evenness and species richness along the pollution gradient are shown in Fig. 5. Diversity varied significantly among transects (Kruskal-Wallis' test, $p<0.01)$. Pairwise Mann-Whitney's $U$ tests showed that 50,100 and $150 \mathrm{~m}$ transects formed a homogeneous group, but had significantly higher diversity values than the 0,200 and $250 \mathrm{~m}$ transects $(p<0.05)$. This indicates that diversity reached a maximum in the semi-polluted area, decreasing towards both extremes of the pollution gradient. Species richness was low at $0 \mathrm{~m}$, and rose sharply between 0 and $50 \mathrm{~m}$. Although species richness was high in transects
$0-50-100 \mathrm{~m}$

Stratification

$150-200-250 \mathrm{~m}$
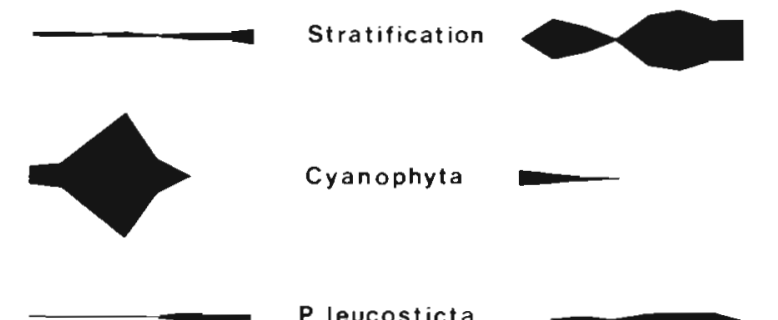

Cyanophyta

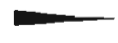

P. leucosticta
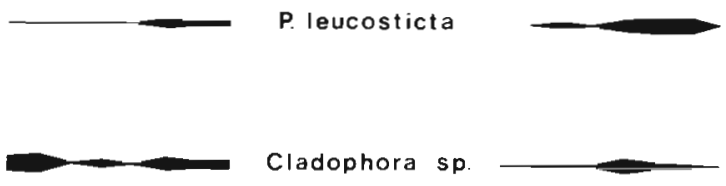

Cladophora sp



S. Iessoni

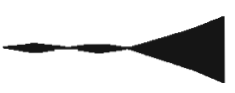

U. Iactuca
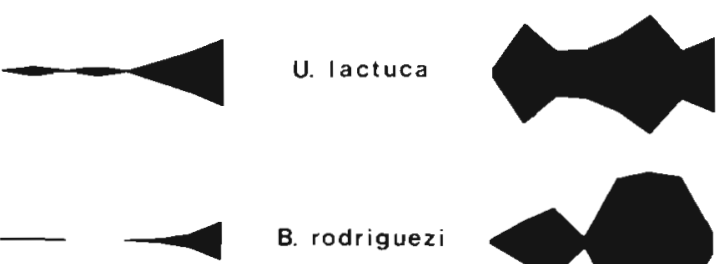

B. rodriguezi
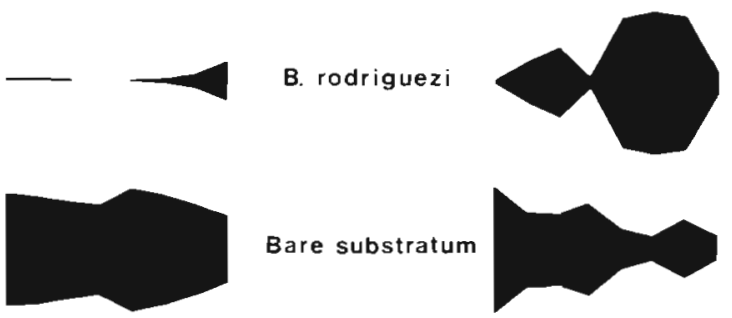

Bare substratum
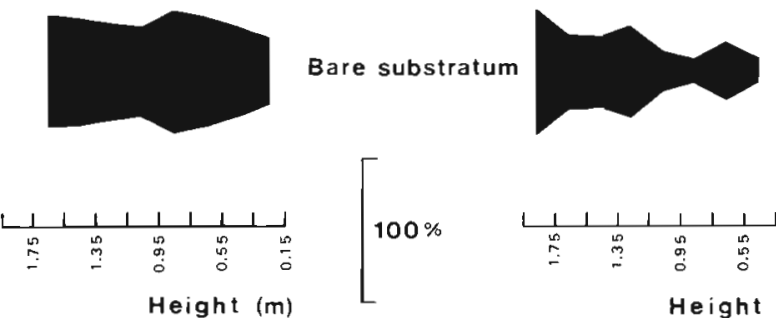

$100 \%$

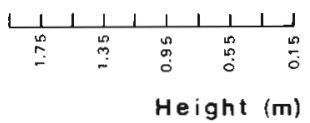

Fig. 4. Stratification, bare substratum proportion, and percent cover of main macrobenthic species as function of relative height. Transects are grouped according to results of Principal Components Analysis (see Fig. 9) 


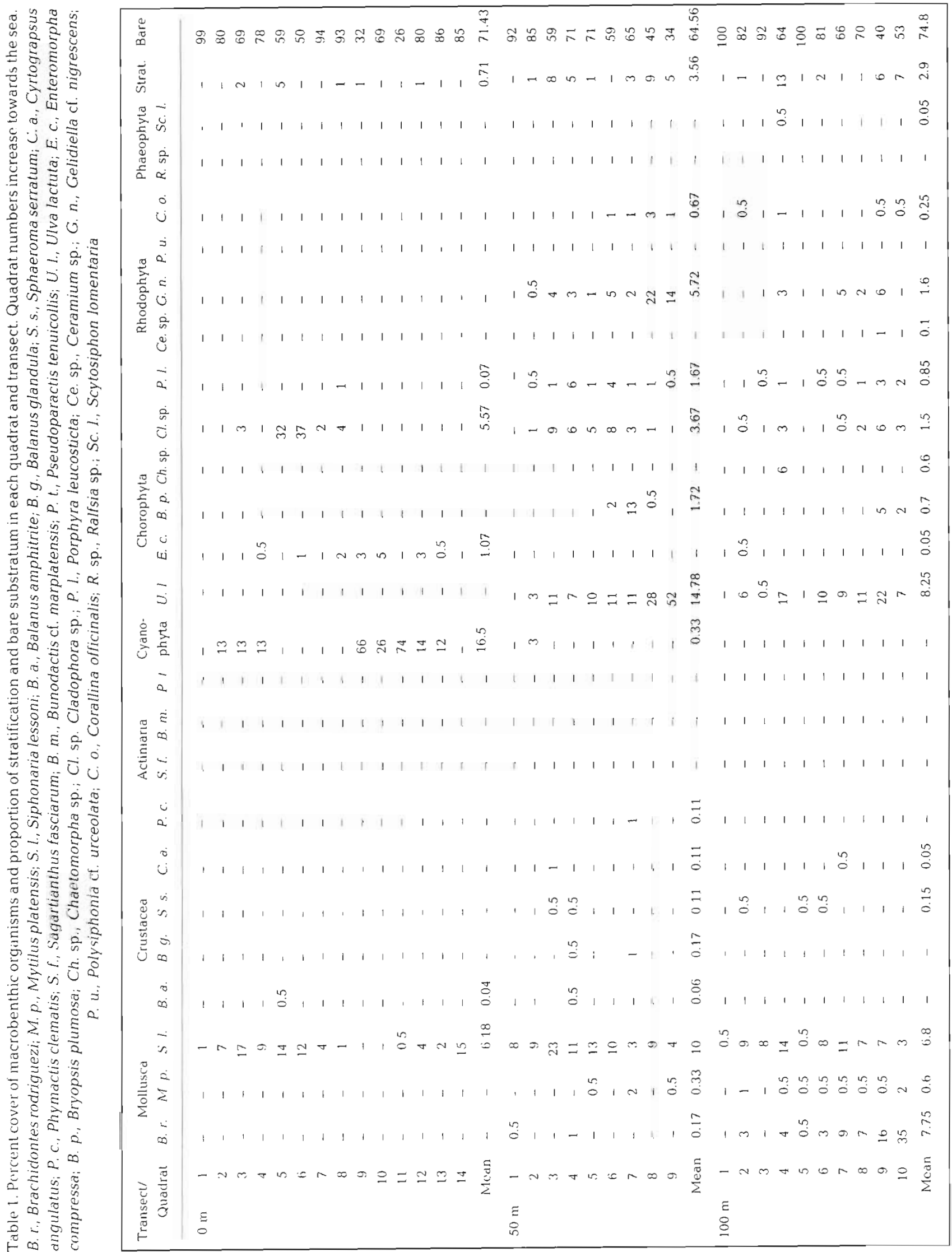




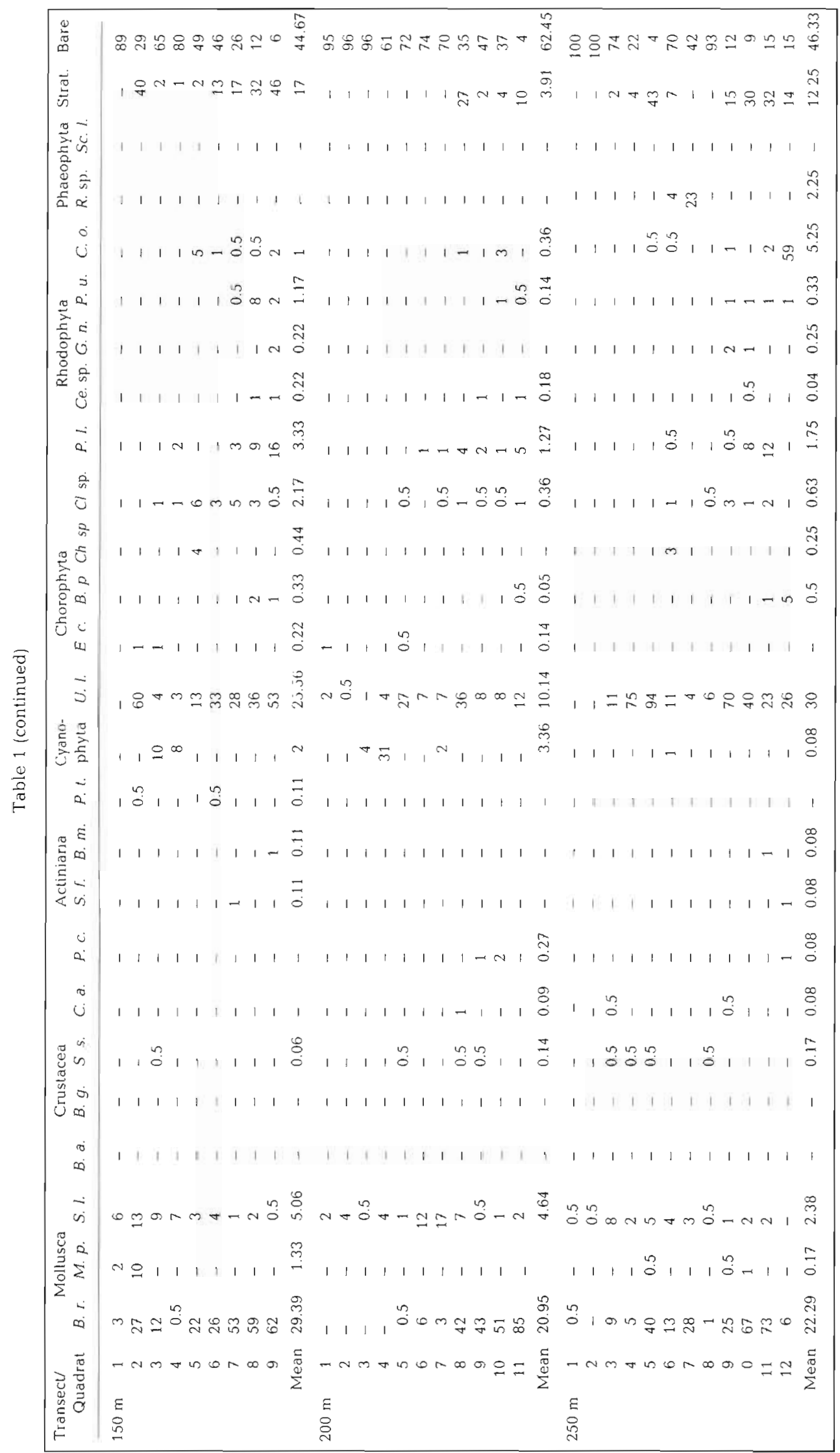



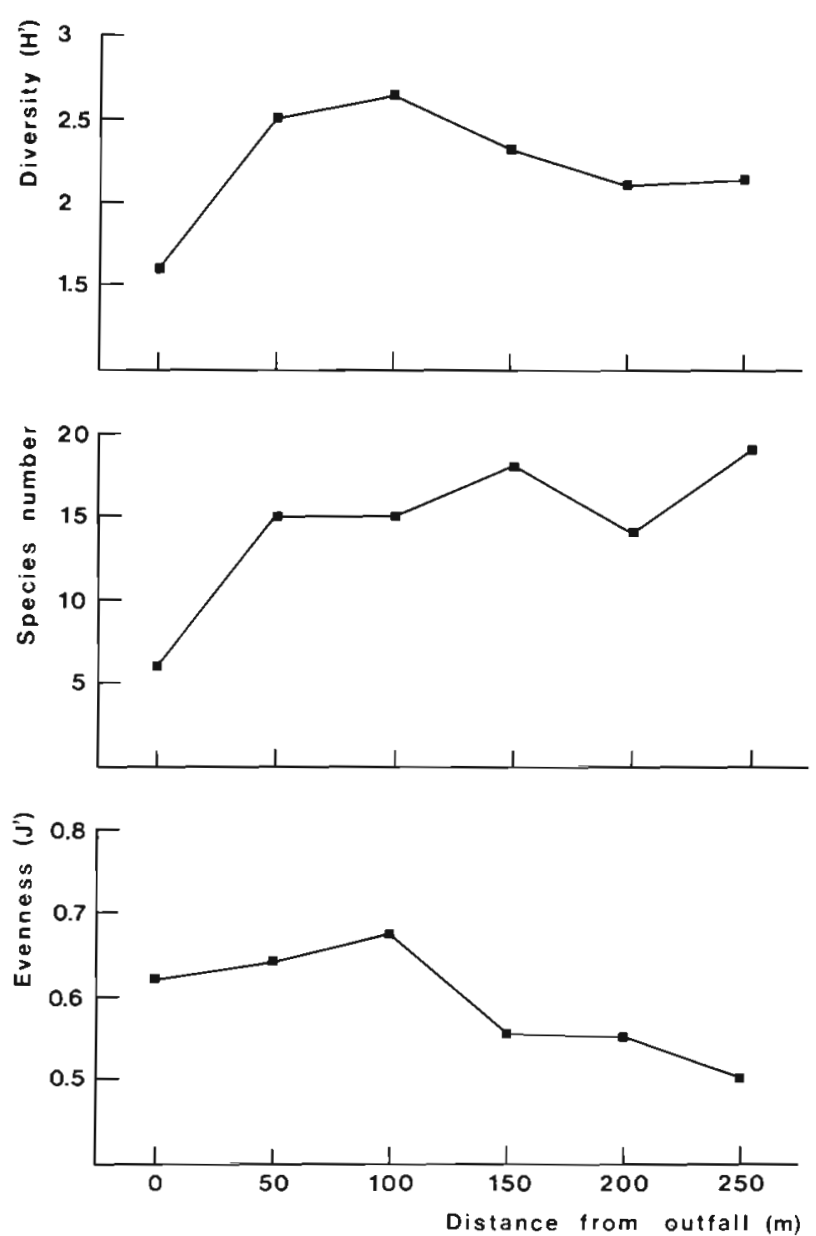

Fig. 5. Diversity $\left(\mathrm{H}^{\prime}\right)$, species richness and evenness $\left(\mathrm{J}^{\prime}\right)$ along the pollution gradient

distant from the outfall $(150,250 \mathrm{~m})$, diversity decreased because of low evenness values related with substrate monopolization by Brachidontes rodriguezi.

Quadrat ordination by PCA is shown in Tables 2 and 3 and Fig. 6. Axes I to VI account for $97.59 \%$ of the variance and are made up mainly by the following species:

Axis I: Brachidontes rodriguezi + Ulva lactuca

Axis II: U. lactuca + B. rodriguezi

Axis III: Cyanophytes
Table 2. Principal Component Analysis of quadrats. Variance and cumulative variance accounted for by Axes I to VI

\begin{tabular}{|rcc|}
\hline Axis & Variance $\%$ & Cumulative variance \% \\
\hline I & 54.61 & 54.61 \\
II & 20.15 & 74.76 \\
III & 13.53 & 88.29 \\
IV & 4.56 & 92.85 \\
V & 3.24 & 96.09 \\
VI & 1.5 & 97.59 \\
\hline
\end{tabular}

Axis IV: Corallina officinalis

Axis V: Cladophora sp. + Siphonaria lessoni

Axis VI: S. lessoni + Cladophora sp.

Fig. 7 shows a dendrogram based on the Mean Character Difference index, by which quadrats were classified in 5 groups. Four of these can be discriminated by a plot of Axes I and II of the PCA (Fig. 6, see also Fig. 2). They are:

Group 1: Quadrats with high proportions of unoccupied substratum (34 to $100 \%, \bar{x}=76.1 \%$ ). It includes 46 quadrats distributed along the whole intertidal in the 0,50 and $100 \mathrm{~m}$ transects, but restricted to the upper intertidal in transects located away from the outfall (150 to $250 \mathrm{~m}$ ). With few exceptions, they occurred at higher levels than quadrats belonging to Group 3 .

Group 2: Crusts of blue-green algae in the vicinity of the pipeline breakage, where they reached a percent cover value of 66 to $74 \%$.

Group 3: Community of Brachidontes rodriguezi. It occurred at lower levels in transects between 100 and $250 \mathrm{~m}$. These 12 quadrats were characterized by the dominance of $B$. rodriguezi $(26$ to $85 \%, \bar{x}=52 \%$ ) and low proportions of bare substratum ( 4 to $53 \%, \bar{x}=28 \%$ ).

Group 4: Tide-pools dominated by UIva lactuca $(60$ to $94 \%, \bar{x}=75 \%$ ) at the 150 and $250 \mathrm{~m}$ transects.

Group 5 consists of only one subtidal quadrat dominated by Corallina officinalis. It is discriminated by Axis IV of the PCA (Table 3).

Table 4 shows values for several biotic and abiotic seawater parameters obtained at the 6 transects used for benthos sampling. A pronounced increase in temperature, $\mathrm{BOD}_{5}$, and number of total and coliform bac-

Table 3. Pnncipal Component Analysis of quadrats. Contribution of main macrobenthic taxa to Axes I to VI

\begin{tabular}{|c|c|c|c|c|c|c|}
\hline Axis & I & II & III & IV & $\mathrm{V}$ & VI \\
\hline Brachidontes rodriguezi & 0.730 & -0.667 & 0.040 & 0.001 & 0.054 & 0.074 \\
\hline Ulva lactuca & 0.657 & 0.724 & 0.189 & -0.058 & 0.018 & -0.031 \\
\hline Cyanophyta & -0.166 & -0.104 & 0.967 & -0.027 & 0.141 & 0.067 \\
\hline Corallina officinalis & 0.019 & 0.061 & -0.017 & 0.937 & 0.299 & 0.145 \\
\hline Cladophora sp. & -0.023 & -0.004 & -0.108 & -0.215 & 0.869 & -0.426 \\
\hline Siphonaria lessoni & -0.047 & 0.065 & -0.119 & -0.252 & 0.357 & 0.862 \\
\hline
\end{tabular}




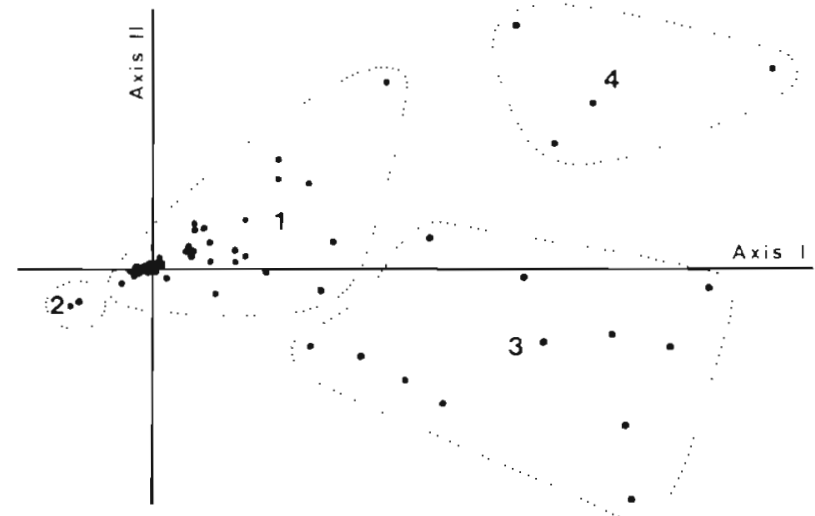

Fig. 6. Principal Components Analysis of quadrats. Quadrats are grouped according to clusters obtained from dendrogram shown in Fig. 7. Group numbers as in Fig. 2

teria was observed close to the outfall (0 to $50 \mathrm{~m}$ ), together with a decrease in salinity, $\mathrm{pH}$ and $\mathrm{DO}$. A PCA based on $\mathrm{pH}, \mathrm{DO}, \mathrm{BOD}_{5}$, temperature, salinity, and total bacteria produced a first axis accounting for $96.51 \%$ of the variance, which indicates high correlation among these 6 variables. Since their contributions to Axis I are important, transect scores on this axis can be regarded as a measure of pollution degree. These scores clearly separate the 0 and $50 \mathrm{~m}$ transects, with negative values, from the other $4(100$ to $250 \mathrm{~m})$, which have similar positive scores (Fig. 8).

A PCA of transects based on percent cover of 24 macrobenthic species (Fig. 9) shows some differences with respect to that performed on seawater variables. Transects are separated into 2 groups along Axis I $(77.14 \%$ of the variance), but in this case the $100 \mathrm{~m}$ transect is closer to the 0 and $50 \mathrm{~m}$ transects and distant from the other 3 (Fig. 8). In addition, the $200 \mathrm{~m}$ transect, which has the greatest average height $(1.38 \mathrm{~m}$. Table $4)$, is much closer to the $0 / 50 / 100 \mathrm{~m}$ group than could be expected according to seawater variables. Transect score ranks on Axis II (15.35\% of the variance) are almost exactly the same as transect height ranks along the shore (Fig. 9, Table 4).

\section{DISCUSSION}

The fact that Brachidontes rodriguezi extensively dominated the intertidal benthic community in the study area, constituting a 'monoculture' as defined by Paine (1984), reflects its success in competition for space. However, substrate monopolization by $B$. rodri-

Fig. 7. Classification of quadrats by dendrogram constructed using Mean Character Difference index. C.C. C.: cophenetic correlation coefficient. Quadrat groups numbered as in Figs. 2 and 6

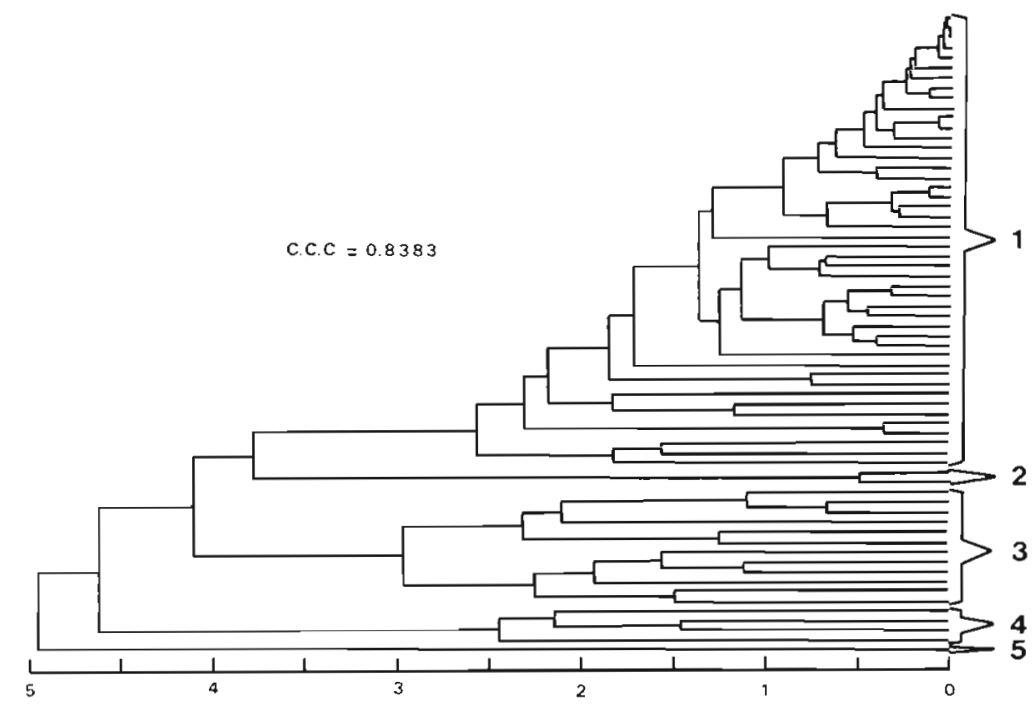

Table 4. Biotic and abiotic seawater variables and average substratum height in 6 transects located at increasing distances to the

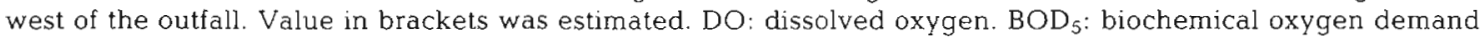

\begin{tabular}{|c|c|c|c|c|c|c|}
\hline Distance from outfall (m) & 0 & 50 & 100 & 150 & 200 & 250 \\
\hline Temperature $\left({ }^{\circ} \mathrm{C}\right)$ & 15 & 14.5 & 14 & 14 & 14 & 14 \\
\hline $\mathrm{pH}$ & 7.87 & 8.02 & 8.14 & 8.12 & 8.15 & 8.16 \\
\hline Salinity (\%o) & 20.3 & 23.5 & 24.0 & 24.1 & 24.4 & 24.1 \\
\hline $\mathrm{DO}\left(\mathrm{mg} \mathrm{l}^{-1}\right)$ & 5.80 & 7.45 & 8.45 & 8.50 & 8.55 & 8.60 \\
\hline $\mathrm{BOD}_{5}\left(\mathrm{mg} \mathrm{O}_{2} \mathrm{l}^{-1}\right)$ & 72 & 32 & $>17.2$ & 10.5 & 8 & (8) \\
\hline Total bacteria $\mathrm{ml}^{-1}$ & 7800 & 1555 & 835 & 1785 & 1290 & 1340 \\
\hline Coliform bacteria $\mathrm{ml}^{-1}$ & $>7$ & $>7$ & 7 & 7 & 0.62 & 2.40 \\
\hline Average height (m) & 1.37 & 0.76 & 0.86 & 1.25 & 1.38 & 1.22 \\
\hline
\end{tabular}




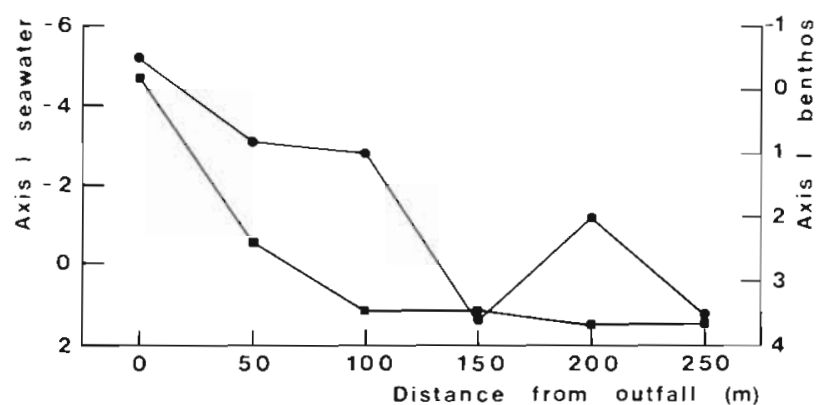

Fig. 8. Comparison of transect scores on Axis I of Principal Components Analysis based on (u) seawater variables and ( $\bullet$ macrobenthic abundance



Fig. 9. Principal Components Analysis of transects according to abundance of macrobenthic species

guezi is not only due to its competitive abilities but also to the absence of important predators at the intertidal level (Paine 1966, 1971, 1974, Russ 1980). Although mytilid predation by asteroideans has great ecological significance in shelf waters off Buenos Aires Province (Penchaszadeh 1973b, 1979), there are neither starfishes nor other invertebrates that could be regarded as important controls of intertidal mytilid populations in this area. Phymactis clematis and Bunodactis marplatensis feed mainly on juveniles of $B$. rodriguezi and only exceptionally on adults (Zamponi 1979b). On the other hand, the abundance of valves in debris accumulated at high tide level indicates the importance of physical disturbances such as wave action in producing free space patches.

The Brachidontes rodriguezi community showed a gradual recovery in lower levels of the $100 \mathrm{~m}$ transect with better water renewal and shorter dessication periods, and at the $150 \mathrm{~m}$ transect the community had attained its characteristic appearance. Absence of $B$. rodriguezi from the most heavily polluted area may be attributed to the high proportion of suspended particles contained in sewage, which could negatively affect the filtering mechanism. Another cause is probably an insufficient oxygen supply during low tide, since high $\mathrm{BOD}_{5}$ values could be expected to occur in seawater mixed with sewage retained within the palleal cavity. Calculations based on $\mathrm{DO}$ and $\mathrm{BOD}_{5}$ data shown in Table 4 indicate that seawater microorganisms would consume 11 to $31 \%$ of initially available oxygen at 0 to $50 \mathrm{~m}$ from the outfall, but only $2 \%$ at 200 to $250 \mathrm{~m}$, during an average 3 h dessication period.

Decreased salinity at the outfall vicinity could hardly be regarded as a factor limiting Brachidontes rodriguezi distribution, since this bivalve was found in brackish waters (2.5 to $33 \%$ ) within Quequén Harbor, where it is harmful to cooling water systems of the Necochea Power Station (Bastida \& Brankevich 1981, 1982, Brankevich et al. 1984).

In areas densely populated by Brachidontes rodriguezi, Siphonaria lessoni has direct access to the substratum only at the upper intertidal, whereas in the mid-and lower intertidal it surrounds patches of $B$. rodriguezi or settles on this mytilid as a juvenile (Penchaszadeh 1973a). Absence of $B$. rodriguezi in polluted areas enables $S$. lessoni to increase in abundance due to greater space and food (blue-green algae, diatoms and other epilithic organisms) availability throughout the intertidal.

Abundance of cyanophytes and filamentous chlorophytes (such as Cladophora sp. and Enteromorpha compressa in this study) near outfalls has been frequently reported in the literature (Borowitzka 1972 , Munda 1974, 1980a, b, Littler \& Murray 1975). Murray \& Littler (1978) pointed out that sewage-impacted epilithic systems represent resilient disclimax communities characterized by their potential for rapid recovery after disturbance. They are composed of opportunistic species with high growth rates, productivity, calorific value and reproductive ability (Littler \& Murray 1978).

Whereas Balanus amphitrite and B. glandula are absent in areas monopolized by Brachidontes rodriguezi, they can be found as isolated individuals near the outfall. B. amphitrite is also present within Quequén Harbor (Bastida \& Brankevich 1982) and B. glandula has increased its abundance in Mar del Plata Harbor during recent years (Spivak \& L'Hoste unpubl.). The Mar del Plata rocky intertidal, which was devoid of barnacles until 1965 (Olivier et al. 1966), is now heavily populated by $B$. glandula, probably due to increasing pollution in the area (Penchaszadeh 1973a).

Previous studies have shown that increasing sewage pollution levels decrease species number and increase total biomass of the affected benthic community. Benthic diversity is low because a few opportunistic species tend to become dominant in the polluted zone (Borowitzka 1972, Anger 1975b), which in extreme circumstances can be completely azoic (Leppäkoski 
1975). Although biomass variation along the pollution gradient was not directly assessed, percent cover data of main species, community stratification and changes in bare substratum (Figs. 3 and 4 ) indicate a biomass decrease of the epilithic community in the surroundings of effluent discharge. The absence of Brachidontes rodriguezi and associated species is not compensated by the increase in cyanophyte, Cladophora sp. and Siphonaria lessoni populations, so that extensive areas remain unoccupied by macrobenthic organisms. However, the presence of dense infaunal populations of Boccardia sp. in the highly polluted area certainly plays an important role in degrading the large amounts of organic matter discharged through the outfall

Changes in diversity, evenness and specific richness along the pollution gradient observed during this survey differ from results obtained by other authors and are probably related to the effects of competence, predation and disturbance on benthic communities. Whereas most previous investigations describe sewage impact on communities dominated by macrophytes (Borowitzka 1972, Jones 1973, Munda 1974, 1980a, b, 1982, Littler \& Murray 1975, 1978, Murray \& Littler 1978) or on infaunal soft bottoms (Marcotte \& Coull 1974, Anger 1975a, b, Leppäkoski 1975, Mearns \& Word 1982), the present study deals with an epilithic community dominated by mytilid bivalves. Although low diversity and specific richness in the neighbourhood of the outfall could be predicted on the basis of previous studies, the decrease in diversity observed in transects located away from the outfall (200 and $250 \mathrm{~m}$ ) was unexpected. This decrease was not due to a drop in species number but to low evenness values resulting from space monopolization by Brachidontes rodriguezi.

If sewage pollution is regarded as a form of disturbance (Dayton 1971), we can conclude like Osman (1977) that there is an optimal degree of disturbance at which diversity reaches a maximum. Higher or lower disturbance levels cause a decrease in diversity, in the first case due to low species number and in the second as a result of dominance by a successful competitor

Variations in abundance of Ulva lactuca along the pollution gradient at Quequén did not follow the same pattern observed in congeneric species in the nothern hemisphere (Littler \& Murray 1975, Munda 1980b). An increase of $U$. lactuca with higher pollution levels was not observed in the present study. Although $U$. lactuca is the most abundant species at the 50 and $100 \mathrm{~m}$ transects, it reaches peak cover values in transects located away from the outfall.

Differences in transect ordination between PCAs based on seawater variables and on macrobenthic species percent cover (Fig. 8) indicate that the effect of sewage pollution stress can hardly be distinguished from the natural decrease in abundance observed towards upper intertidal levels. In both cases the Brachidontes rodriguezi community gradually disappeared, with a consequent increase in the proportion of bare substratum. Thus, similar benthic communities developed in relatively high, non-polluted areas $(200 \mathrm{~m}$ transect) and in deeper but polluted ones $(50$ and $100 \mathrm{~m}$ transects) (Figs. 2 and 8, Table 4).

The different relative position of the $100 \mathrm{~m}$ transect in the 2 PCAs (Fig. 8) can be attributed to the ability of benthic communities to reflect not only conditions at the time of sampling but also conditions at some earlier time (Reish 1987). Seawater analyses were performed under 'normal' weather conditions, during which the effluent is directed eastward by the coastal current. However, easterly winds may occasionally alter the usual pattern and extend the influence of polluted waters further to the west. The macrobenthic community is composed of organisms with relatively long life spans, which reflect an average of different environmental conditions prevailing through time. Hence, they can be regarded in this case as better pollution indicators than seawater parameters present at a given moment.

Acknowledgements. We sincerely thank the authorities and staff of the following institutions: Argentine Museum of Natural Sciences Bernardino Rivadavia', Puerto Quequén Hydrobiological Station and Supporting Cooperative Association, Department of Public Works and Services and Department of Public Health of Necochea Municipality, and DEBA. Power Station (Laboratory of Chemistry), Necochea. We are also indebted to Osvaldo O. Vanone, Teodoro Stadler, María A. Lluch, Claudia Sciuto, María L. Piriz, Alicia Boraso, Carmen Pujals and Elena Gōmez Simes. Analía Amor, Victoria Lichtschein, Pablo Penchaszadeh, Sebastian Gerlach and 2 anonymous reviewers are acknowledged for their critical reading of the manuscript. This research was partly supported by a PID grant No. 035/88 from the National Council for Scientific Research and Technology (CONICET).

\section{LITERATURE CITED}

American Public Health Association (1971). Standard methods for the examination of water and wastewater. Washington, D.C.

Anger, K. (1975a). On the influence of sewage pollution on inshore benthic communities in the south of Kiel Bay. Part 1 Qualitative studies on indicator species and communities. Merentutkimuslait. Julk. 239: 116-122

Anger, K. (1975b). On the influence of sewage pollution on inshore benthic communities in the South of Kiel Bay. Part 2. Quantitative studies on community structure. Helgoländer wiss. Meeresunters. 27: 408-438

Anger, K. (1977). Benthic invertebrates as indicators of organic pollution in the Western Baltic Sea. Int. Revue ges. Hydrobiol. 62 (2) : 245-254

Bastida, R., Brankevich, G. (1980). Estudios ecológicos preliminares sobre las comunidades incrustantes de Puerto Quequén (Argentina). In: Proc. Fifth Int. Congr Marine Corrosion and Fouling, Mar. Biol, Barcelona, p. 113-138 
Bastida, R., Brankevich, G. (1981). Estudios ecológicos sobre las comunidades incrustantes de Puerto Quequén (Argentina). I. Características del microfouling. CIDEPINT Anales 1981: 199-232

Bastida, R., Brankevich, G. (1982). Estudios ecológicos sobre las comunidades incrustantes de Puerto Quequén (Argentina). II. Caracteristicas del macrofouling. CIDEPINT Anales 1982: 157-193

Bastida, R., Capezzani, A., Torti, M. R. (1971). Fouling organisms in the port of Mar del Plata (Argentina). I. Siphonaria lessoni ecological and biometric aspects. Mar Biol. 10 (4): 297-307

Borowitzka, M. A. (1972). Intertidal algal species diversity and the effect of pollution. Aust. J. mar. Freshwat. Res. 23 (2): 73-84

Brankevich, G., Bastida, R., Lemmi, C. (1988). A comparative study of biofouling settlements in different sections of Necoched Power Plant (Quequén Port, Argentina). Biofouling 1. 113-135

Branchevich, G., Bastida, R., Martinez, D. (1984). Ecological aspects of marine fouling at the Necochea Power Plant (Puerto Quequén, Argentina). In: Proc. Sixth Int. Congr Marine Corrosion and Fouling, Mar Biol., Athens, p. $567-583$

Cain, A. J., Harrison, G. A. (1958). An analysis of the taxonomist's judgement of affinity. Proc. Zool. Soc. Lond. 131: $85-98$

Dayton, P. K. (1971). Competition, disturbance, and community organization: the provision and subsequent utilization of space in a rocky intertidal community. Ecol. Monogr. 41: 351-389

Gerlach, S. A. (1981). Marine pollution. Diagnosis and therapy. Springer-Verlag, Berlin

Jones, D. J. (1973). Variation in the trophic structure and species composition of some invertebrate communities in polluted kelp forests in the North Sea. Mar Biol. 20: 351-365

Leppäkoski, E. (1975). Assessment of degree of pollution on the basis of macrozoobenthos in marine and brackishwater environments. Acta Acad. Aboensis, Ser B 35 (2): $1-96$

Leppäkoski, E. (1979). The use of zoobenthos in evaluating effects of pollution in brackish-water environments. In: The use of ecological variables in environmental monitoring. Nat. Swed. Env. Prot. Board, Rep. PM 1151: 151-158

Littler, M. M., Murray, S. N. (1975). Impact of sewage on the distribution, abundance and community structure of rocky intertidal macro-organisms. Mar Biol. 30: 277-291.

Littler, M. M., Murray, S. N. (1977). Influence of domestic wastes on the structure and energetics of intertidal communities near Wilson Cove, San Clemente Island. Calif. Wat. Res. Cent., Univ. Calif., Davis, Contr. No. 164, p. 1-88

Littler, M. M. Murray, S. N. (1978). Influence of domestic wastes on energetic pathways in rocky intertidal communities. J. appl. Ecol. 15: 583-596

Marcotte, B. M., Coull, B. C. (1974). Pollution, diversity and meiobenthic communities in the North Adriatic Bay of Piran, Yugoslavia, Vie Milieu, Ser B Oceanogr. 24 (2): 281-300

Mearns, A. J., Word, J. Q. (1982). Forecasting effects of sewage solids on marine benthic communities. In: Mayer, $G$. F. (ed.) Ecological stress and the New York Bight: science and management. Estuar Res. Fed., Columbia, S.C., p. $495-512$

Munda, I. M. (1974). Changes and succession in the benthic algal associations of slightly polluted habitats. Revue int. Océanogr med. 34: 37-52
Munda, I. M. (1980a). Changes in the benthic algal associat.ons of the vicinity of Rovinj (Istrian Coast, North Adriatic) caused by organic wastes. Acta adriat. 21 (2): 299-332

Munda, I. M. (1980b). Survey of the algal biomass in the polluted area around Rovinj (Istrian Coast, North Adriatic). Acta adriat. 21 (2): 333-354

Munda, I. M. (1982). The effect of different pollutants on benthic marine alga. In: VI Jour. Etud. Pollut., C. I. E. S. M., Cannes, p. 721-726

Murray, S. N. Littler, M. M. (1978). Patterns of algal succession on a perturbated marine intertidal community. J. Phycol. 14: 506-512

Neff, N. A., Marcus, L. F. (1980). A survey of multivariate methods for systematics. Am. Mus. Nat. Hist., New York

Olivier, S. R., Escofet, A., Orensanz, J. M., Pezzani, S. E. Turro, A. M., Turro, M. E. (1966). Contribución al conocimiento de las comunidades bénticas de Mar del Plata. I El litoral rocoso entre Playa Grande y Playa Chica. An Comn. Invest. cient. Prov. B. Aires 7: 185-206

Olivier, S. R., Penchaszadeh, P. E. (1968). Observaciones sobre la ecología y biología de Siphonaria (Pachysiphonaria) lessoni (Blainville, 1824) (Gastropoda, Siphonariidae) en el litoral rocoso de Mar del Plata (Buenos Aires). Cah. Biol. mar. 9: 469-491

Osman, R. (1977). The establishment and development of a marine epifaunal community. Ecol. Monogr 47: 37-63

Paine, R. T. (1966). Food web complexity and species diversity. Am. Nat. 100: 65-75

Paine, R. T (1971). A short-term experimental investigation of resource partitioning in a New Zealand intertidal habitat. Ecology 52 (6): 1096-1106

Paine, R. T (1974). Intertidal community structure: experimental studies on the relationship between a dominant competitor and its principal predator. Oecologia (Berl.) 15: 93-120

Paine, R. T. (1984). Ecological determinism in the competition for space. Ecology 65 (5): 1339-1348

Penchaszadeh, P. E. (1973a). Ecología de la comunidad del mejilín (Brachydontes rodriguezi d'Orb.) en el mediolitoral rocoso de Mar del Plata (Argentina): el proceso de recolonización. Physis, B. Aires, Secc. A Océanos sus Org. 32 (84): 51-64

Penchaszadeh, P. E. (1973b). Comportamiento trófico de la estrella de mar Astropecten brasiliensis. Ecología (B. Aires) 1. $45-54$

Penchaszadeh, P. E. (1979). Estructura de la comunidad y procesos que la determinan en bancos circalitorales de mejillón Mytilus platensis. In: Memorias del Seminario sobre Ecología Bentonica y Sedimentación de la Plataforma. Continental del Atlántíco Sur. UNESCO, Montevideo, p. 131-147

Pielou, E. C. (1969). An introduction to mathematical ecology. Wiley-Interscience, New York

Reish, D. J. (1986). Benthic invertebrates as indicators of marine pollution: 35 years of study. In: IEEE Oceans' 86 Conf. Proc, Washington, D.C., p. 885-888

Reish, D. J. (1987). The use of benthic communities in marine environmental assessment In: Malagrino, G., Santoyo, H. (eds.) Mem. V Simp. Biol. Mar., Univ. Auton. Baja Calif. Sur. La Paz, Mexico, p. 123-126

Romesburg, H. C. (1984). Cluster analysis for researchers. Lifetime Learning Publications, Belmont, California

Russ, G. R. (1980). Effect of predation by fishes, competition, and structural complexity of the substratum on the establishment of a marine epifaunal community. J. exp. mar. Biol. Ecol. 42: 65-69 
Shannon, C. E., Weaver, W (1949). The mathematical theory of communication. The University of Illinois Press, Urbana Siegel, S. (1956). Nonparametric statistics for the behavioral sciences. McGraw-Hill, New York

Sokal, R. R., Rohlf, F. J. (1962). The comparison of dendrograms by objective methods. Taxon 11:33-41

Young, M. W., Young, D. K. (1982). Marine macrobenthos as indicators of environmental stress. In: Mayer, G. F. (ed.)

This article was presented by Professor S. A. Gerlach, Kiel, F.R. Germany
Ecological stress and the New York Bight: science and management. Estuar. Res. Fed., Columbia, S.C., p. 527-539 Zamponi, M. O. (1979a). El desarrollo asexual de Pseudoparactis tenuicollis McMurrich, 1904 (Actiniaria: Actinostolidae) y algunas consideraciones sobre su ecología. Acta zool. lilloana 35: 595-602

Zamponi, M. O. (1979b). Sobre la alimentación en Actinuaria (Coelentherata: Anthozoa). Neotrópica 25 (74) 195-200

Manuscript first received: November 21, 1989 Revised version accepted: March 1, 1990 